\title{
Evaluation of DNA damage in an Ecuadorian population exposed to glyphosate
}

\author{
César Paz-y-Miño ${ }^{1,2}$, María Eugenia Sánchez ${ }^{1,2}$, Melissa Arévalo $^{1}$, María José Muñoz ${ }^{1}$, Tania Witte ${ }^{1}$, \\ Gabriela Oleas De-la-Carrera ${ }^{1}$ and Paola E. Leone $e^{1,2}$ \\ ${ }^{1}$ Laboratorio de Genética Molecular y Citogenética Humana, Escuela de Biología, \\ Pontificia Universidad Católica del Ecuador, Quito, Ecuador. \\ ${ }^{2}$ Unidad de Genética, Facultad de Medicina, Pontificia Universidad Católica del Ecuador, Quito, Ecuador.
}

\begin{abstract}
We analyzed the consequences of aerial spraying with glyphosate added to a surfactant solution in the northern part of Ecuador. A total of 24 exposed and 21 unexposed control individuals were investigated using the comet assay. The results showed a higher degree of DNA damage in the exposed group (comet length $=35.5 \mu \mathrm{m}$ ) compared to the control group (comet length $=25.94 \mu \mathrm{m}$ ). These results suggest that in the formulation used during aerial spraying glyphosate had a genotoxic effect on the exposed individuals.
\end{abstract}

Key words: comet assay, DNA damage, Ecuador, genotoxicity, glyphosate.

Received: May 24, 2006; Accepted: November 7, 2006.

Glyphosate is a non-selective herbicide which is the main chemical component in many systemic herbicides used to control most annual and perennial plants. It controls weeds by inhibiting the synthesis of aromatic amino acids necessary for protein formation, which link primary and secondary metabolism in susceptible plants (Carlisle and Trevors, 1988; U.S. Forest Service, 1997).

According to some reports glyphosate shows no adverse effects on soil microorganisms, it is relatively nontoxic to fish (U.S. Forest Service, 1997) and is of relatively low toxicity to birds and mammals, including humans (Batt et al., 1980; Evans and Batty, Williams et al., 2000; Goldstein et al., 2002). However, Lioi et al., (1998) reported de induction of oxidative stress and mutagenic effects for some pesticides, including glyphosate, in bovines and Paz-y-Miño et al., (2002a) reported that some pesticides were associated with genetic damage in human populations subjected to high pesticide exposure levels due intensive use, misuse or failure of control measures.

Since January 2001, the northern area of Ecuador (mainly Sucumbíos district) has been subjected to aerial spraying by the Colombian Government with RoundupUltra, a herbicide formulation containing glyphosate, poly-

Send correspondence to César Paz-y-Miño. Laboratorio de Genética Molecular y Citogenética Humana, Escuela de Biología, Facultad de Ciencias Exactas y Naturales, Pontificia Universidad Católica del Ecuador, P.O. Box 17-01-2184 Quito, Ecuador. E-mail: cpazymino@puce.edu.ec ethoxylated tallowamine surfactant (POEA) and the adjuvant Cosmoflux 411F which is a propriety Colombian component probably included to aid the adherence or absorption of the herbicide (Ministerio de Relaciones Exteriores, Ecuador (MREE), 2003). According to the National Narcotic Council for air spraying of illicit cultures the load of the airplane was 1137 to 1705 liters and the effective unloading with Roundup Ultra (43.9\% of glyphosate) was 23.4 liters $\mathrm{ha}^{-1}$ equivalent to $10.3 \mathrm{~L} \mathrm{ha}^{-1}$ of glyphosate (Acción Ecológica, 2003, Nivia, 2001). The main purpose of spraying glyphosate in this formulation is to eradicate illicit crops grown in this area, and several research projects have been carried out to investigate the consequences of the use of this formulation in Ecuador (MRE, Ecuador, 2003; Acción Ecológica, 2003).

The comet assay can be used to evaluate DNA damage and provides a useful tool for estimating the genetic risk from exposure to complex mixtures of chemicals (Paz-y-Miño et al., 2002b), this assay having been widely applied in genotoxicity studies of factors such as X-rays and pesticides (Singh et al., 1988; Tice et al., 1990; Scarpato et al., 1996; Slamenová et al., 1999; Blasiak et al; 1999; Garaj-Vrhovac and Zeljezic, 2000; Paz-y-Miño et al., 2002a; Paz-y-Miño et al., 2002b; Acción Ecológica, 2003).

The aim of the study described in this paper was to determine the possible influence of the formulation of 
glyphosate used during aerial spraying in northern Ecuador on the genetic material of exposed individuals.

The exposed (E) group consisted of 24 randomly selected individuals (Table 1) who lived $3 \mathrm{~km}$ or less from an area on the border between Ecuador and Colombia where aerial spraying with a glyphosate-based herbicide had occurred continuously during three days between December 2000 and March 2001, sporadic aerial spraying continuing for three weeks following continuous spraying (MREE, 2003, Acción Ecológica 2004). Exposed group individuals manifested symptoms of toxicity after several exposures to aerial spraying, with half of the individuals in this group having received spraying directly over their houses and the other half living within $200 \mathrm{~m}$ to $3 \mathrm{~km}$ from the sprayed areas.

A clinical history was completed for each of the exposed individuals and a wide-range of reactions were noted, including intestinal pain and vomiting, diarrhea, fever, heart palpitations, headaches, dizziness, numbness, insomnia, sadness, burning of eyes or skin, blurred vision, difficulty in breathing and blisters or rash (MREE, 2003; Acción Ecológica 2003).
Venous blood $(5 \mathrm{~mL})$ was taken from the exposed individuals between two weeks and two months after their exposure to aerial spraying and processed immediately after collection.

The blood samples analyzed in this study were provided by Dr. Adolfo Maldonado, a specialist in tropical medicine and a member of the Ecological Action foundation and part of the group of investigators of the International Commission on the Impact on Ecuadorian Territory of Aerial Fumigations in Colombia. This study was approved by the Bioethics Committee of the Pontifical Catholic University of Ecuador, according to the international guidelines. Each individual completed a personal and biomedical survey and gave their informed consent to be part of this study. In the case of the adolescents involved in the study (14-17 year-olds) their legal guardians, as well as themselves, gave their informed consent.

All of the individuals included in this study combine their activities mainly in the house and sometimes cultivating and harvesting. This persons neither used herbicides, pesticides nor similar substances in the named activities (Acción Ecológica, 2004).

Table 1 - DNA damage assessed by the comet assay in individuals exposed (E) to glyphosate and unexposed (U) control individuals. Note that the same numbers $(1,2,3$ etc.) for the individuals does not indicate that the exposed and control individuals were matched.

\begin{tabular}{|c|c|c|c|c|c|c|c|c|c|c|c|c|c|c|c|}
\hline \multicolumn{8}{|c|}{ Exposed to glyphosate } & \multicolumn{8}{|c|}{ Unexposed controls } \\
\hline \multirow{2}{*}{$\begin{array}{l}\text { Individual } \\
\text { (gender, } \\
\text { age) }\end{array}$} & \multicolumn{5}{|c|}{ Number of cells scored in each group } & \multicolumn{2}{|c|}{ DNA migration $(\mu \mathrm{m})$} & \multirow{2}{*}{$\begin{array}{l}\text { Individual } \\
\text { (gender, }^{\text {age) }}\end{array}$} & \multicolumn{5}{|c|}{ Number of cells scored in each group } & \multicolumn{2}{|c|}{ DNA migration $(\mu \mathrm{m})$} \\
\hline & A & B & $\mathrm{C}$ & $\mathrm{D}$ & E & Mean & Median & & A & B & $\mathrm{C}$ & $\mathrm{D}$ & $\mathrm{E}$ & Mean & Median \\
\hline $1 \mathrm{E}(\mathrm{F}, 53)$ & 2 & 120 & 76 & 5 & 3 & 39.5 & 32.5 & $1 \mathrm{U}(\mathrm{F}, 17)$ & 150 & 59 & 3 & 0 & 0 & 26.2 & 25.0 \\
\hline $2 \mathrm{E}(\mathrm{F}, 37)$ & 13 & 92 & 82 & 14 & 0 & 44.1 & 32.5 & $2 \mathrm{U}(\mathrm{F}, 40)$ & 164 & 43 & 4 & 0 & 0 & 25.4 & 25.0 \\
\hline $3 \mathrm{E}(\mathrm{F}, 40)$ & 2 & 64 & 62 & 77 & 4 & 56.6 & 52.5 & $3 \mathrm{U}(\mathrm{F}, 26)$ & 165 & 40 & 2 & 0 & 0 & 25.7 & 25.0 \\
\hline $4 \mathrm{E}(\mathrm{M}, 27)$ & 8 & 75 & 64 & 47 & 8 & 49.2 & 37.5 & $4 \mathrm{U}(\mathrm{M}, 14)$ & 111 & 96 & 6 & 0 & 0 & 27.3 & 26.5 \\
\hline $5 \mathrm{E}(\mathrm{F}, 44)$ & 9 & 138 & 63 & 3 & 0 & 34.6 & 30.0 & $5 \mathrm{U}(\mathrm{M}, 32)$ & 165 & 38 & 3 & 0 & 0 & 25.9 & 25.0 \\
\hline $6 \mathrm{E}(\mathrm{F}, 50)$ & 51 & 113 & 30 & 3 & 0 & 30.8 & 27.5 & $6 \mathrm{U}(\mathrm{M}, 21)$ & 171 & 35 & 1 & 0 & 0 & 25.7 & 25.0 \\
\hline $7 \mathrm{E}(\mathrm{F}, 38)$ & 21 & 139 & 48 & 3 & 0 & 33.2 & 30.0 & $7 \mathrm{U}(\mathrm{M}, 16)$ & 177 & 25 & 6 & 0 & 0 & 25.8 & 25.0 \\
\hline $8 \mathrm{E}(\mathrm{F}, 46)$ & 21 & 116 & 72 & 4 & 0 & 35.2 & 30.0 & $8 \mathrm{U}(\mathrm{F}, 47)$ & 176 & 25 & 3 & 0 & 0 & 25.7 & 25.0 \\
\hline $9 \mathrm{E}(\mathrm{F}, 55)$ & 26 & 100 & 84 & 1 & 0 & 32.8 & 30.0 & $9 \mathrm{U}(\mathrm{F}, 15)$ & 190 & 14 & 1 & 0 & 0 & 25.2 & 25.0 \\
\hline $10 \mathrm{E}(\mathrm{F}, 50)$ & 26 & 100 & 84 & 1 & 0 & 34.2 & 30.0 & $10 \mathrm{U}(\mathrm{F}, 36)$ & 179 & 25 & 1 & 0 & 0 & 25.4 & 25.0 \\
\hline $11 \mathrm{E}(\mathrm{F}, 22)$ & 28 & 123 & 60 & 0 & 0 & 32.0 & 27.5 & $11 \mathrm{U}(\mathrm{F}, 21)$ & 150 & 46 & 9 & 0 & 0 & 26.3 & 25.0 \\
\hline $12 \mathrm{E}(\mathrm{F}, 27)$ & 11 & 130 & 63 & 6 & 0 & 33.7 & 30.0 & $12 \mathrm{U}(\mathrm{F}, 43)$ & 148 & 49 & 15 & 0 & 0 & 26.8 & 25.0 \\
\hline $13 \mathrm{E}(\mathrm{F}, 28)$ & 40 & 132 & 40 & 2 & 0 & 31.0 & 30.0 & $13 \mathrm{U}(\mathrm{F}, 53)$ & 161 & 27 & 10 & 0 & 0 & 26.1 & 25.0 \\
\hline $14 \mathrm{E}(\mathrm{F}, 59)$ & 10 & 96 & 99 & 1 & 0 & 36.4 & 32.5 & $14 \mathrm{U}(\mathrm{F}, 35)$ & 164 & 23 & 21 & 0 & 0 & 27.0 & 25.0 \\
\hline $15 \mathrm{E}(\mathrm{F}, 55)$ & 35 & 110 & 62 & 1 & 0 & 32.7 & 30.0 & $15 \mathrm{U}(\mathrm{F}, 38)$ & 169 & 28 & 11 & 0 & 0 & 26.4 & 25.0 \\
\hline $16 \mathrm{E}(\mathrm{F}, 17)$ & 60 & 101 & 44 & 1 & 0 & 31.3 & 37.5 & $16 \mathrm{U}(\mathrm{F}, 22)$ & 183 & 15 & 8 & 0 & 0 & 25.1 & 25.0 \\
\hline $17 \mathrm{E}(\mathrm{F}, 34)$ & 7 & 114 & 57 & 2 & 0 & 33.4 & 30.0 & $17 \mathrm{U}(\mathrm{F}, 71)$ & 191 & 8 & 5 & 0 & 0 & 25.0 & 25.0 \\
\hline $18 \mathrm{E}(\mathrm{F}, 45)$ & 10 & 150 & 50 & 4 & 0 & 33.0 & 30.0 & $18 \mathrm{U}(\mathrm{F}, 39)$ & 195 & 13 & 6 & 0 & 0 & 25.5 & 25.0 \\
\hline 19E (F, 28) & 13 & 160 & 44 & 0 & 0 & 31.1 & 27.5 & $19 \mathrm{U}(\mathrm{F}, 21)$ & 179 & 20 & 8 & 0 & 0 & 25.9 & 25.0 \\
\hline $20 \mathrm{E}(\mathrm{F}, 21)$ & 1 & 153 & 47 & 3 & 0 & 33.2 & 30.0 & $20 \mathrm{U}(\mathrm{F}, 50)$ & 190 & 14 & 2 & 0 & 0 & 25.3 & 25.0 \\
\hline $21 \mathrm{E}(\mathrm{F}, 34)$ & 2 & 130 & 25 & 1 & 0 & 31.8 & 30.0 & $21 \mathrm{U}(\mathrm{F}, 43)$ & 150 & 56 & 9 & 0 & 0 & 26.4 & 25.0 \\
\hline $22 \mathrm{E}(\mathrm{F}, 23)$ & 0 & 29 & 173 & 2 & 0 & 39.3 & 37.5 & & & & & & & & \\
\hline $23 \mathrm{E}(\mathrm{F}, 34)$ & 2 & 88 & 115 & 1 & 0 & 35.5 & 37.5 & & & & & & & & \\
\hline
\end{tabular}

${ }^{\mathrm{a}} \mathrm{F}=$ female $; \mathrm{M}=$ male, ${ }^{\mathrm{b}, \mathrm{c}}$ Mean \pm standard deviation $(\mathrm{SD}),{ }^{\mathrm{d}}$ Mean median value $\pm \mathrm{SD}$. 
The unexposed (U) control group consisted of 21 unrelated healthy individuals living $80 \mathrm{~km}$ away from the spraying area. They were similar to the exposed group regarding their demographic characteristics and occupation but were not matched controls. Blood samples were collected and processed as for the exposed group, but not concomitantly.

None of the individuals analyzed in this study (neither the exposed group nor the control group) smoked tobacco, drank alcohol, took non-prescription drugs or had been exposed to pesticides during the course of their normal daily lives. All of the individuals included in this study mainly worked at home, sometimes cultivating and harvesting crops without the use of herbicides, pesticides or similar substances in the named activities and their windowed houses did not contain asbestos in the ceilings or roofs (Acción Ecológica, 2004).

The Comet assay is a rapid and sensitive method for the detection of DNA damage induced in vivo (Singh et al., 1988, McKelvey-Martin et al., 1993, Monroy et al., 2005) or after environmental and occupational exposures (Albertini et al., 1996, Leroy et al., 1996).

The blood samples were assayed using the alkaline comet assay as described by Singh et al., (Singh et al., 1988 ) with the modifications implemented in our laboratory (Paz-y-Miño et al., 2002). The comet assay slides were analyzed at 400x magnification using a Zeiss fluorescence microscope equipped with a calibrated ocular micrometer and a $50 \mathrm{~W}$ mercury lamp with and excitation filter of $515-560 \mathrm{~nm}$ and a $590 \mathrm{~nm}$ barrier filter.

Cells were visually allocated to classified one o five predefined categories (A-E) according to the amount of DNA in the comet's tail, tail and a rank-number of from 0 (A) to 400 (E) was assigned to quantify the damage in each cell and calculate a mean of the amount of DNA damage (Anderson et al., 1994).

To measure the head-to-tail comet length randomlyselected cells from the center of the gel were measured using a calibrated scale and DNA migration was determined by measuring the nuclear DNA and the migrating DNA (Singh et al., 1988).

An average of 200 cells per individual was scored and the mean and median comet length from each individual was used for statistical analysis by the Mann-Whitney U test, which was applied to determine the differences between exposed and control group in the comet assay.

We found that individuals in the group which had been exposed to spraying with the glyphosate-containing herbicide showed higher DNA migration levels than controls $(\mathrm{p}<0.001)$, the exposed group having a mean total migration level of $35.50 \mu \mathrm{m}$ as compared with $25.94 \mu \mathrm{m}$ for the control group (Table 1). Comet types D and E were not observed in the control group (Table 1).

This work reports the results of the cytogenetic monitoring and DNA damage assessment of individuals exposed to aerial spraying of glyphosate in the northern part of Ecuador. A study of the genotoxicity of chemicals, such as glyphosate is important because of their possible consequences on human health and their association with cancer, as has been published in similar studies with pesticides (Paz-y-Miño et al., 2002a). The Alaska Community Action on Toxics (ACAT, 1998) factshhet, other studies like Arbuckle et al., (2001) and Richard et al., (2005) reported that when people ingest or absorb glyphosate through their skin or bathe or drink in water contaminated with this herbicide a wide range of symptoms can occur, such as headaches or reactions which affect the eyes, skin, lungs, heart, blood cells and genitals and gonads. Ecuadorian governmental data confirms the existence of health problems associate with such symptoms in the spraying zone (MREE, 2003)

Published data showed that chromosomal damage induced by pesticides appears to be transient transient in acute or discontinuous exposure but cumulative in continuous exposure to complex agrochemical mixtures (Bolognesi, 2003).

Formulated herbicides containing glyphosate are more potent mutagens to animals and humans than pure glyphosate, most probably due to the concomitant effects of additional toxic components, such as surfactants (ACAT, 1998). The aerial spraying on the border between Ecuador and Colombia used $44 \%$ of Roundup-Ultra (see above) but the recommended application rate of this formulation in the USA is $1.6 \%$ to $7.7 \%$ up to a maximum concentration of 29\% (MREE, 2003) and according to Acción Ecológica (2003) the application rate of the formulated product must not exceed $0.95 \mathrm{~L} \mathrm{ha}^{-1}$. In the area of our study the application rate was $23.4 \mathrm{~L}$ ha-1 $\left(10.3 \mathrm{~L} \mathrm{ha}^{-1}\right.$ with respect to glyphosate) and therefore more than 20 times the maximum recommended application rate for the formulated product, which may explain our comet assay results (Table 1) (Acción Ecológica, 2003, Nivia, 2001).

The analysis of genes implicated in the process of DNA detoxification, would be useful to understand the genetic influence of some chemicals like glyphosate. In our study factors such us age and DNA damage were not found to be related and because most members of the exposed and control groups were female we cannot conclude anything regarding the influence of sex on the results of the comet assay. Similar results have been reported in other investigations, which report that in general terms sex and age seem to have little, if any, effect in pesticide exposed populations (Carbonell et al., 1993, Steenland et al., 1986).

However, we did find a higher degree of DNA damage in the exposed group compared to the control group (Table 1). The significant increase in DNA damage levels observed seem to reflect a general response to the formulation used during aerial spraying, since none of the individuals in the exposed group smoked tobacco or drank alcohol 
or had been exposed to other pesticides when the samples were taken.

Our findings suggest the existence of a genotoxic risk for glyphosate exposure in the formulation used during the aerial sprayings and indicate the need for further studies on individuals exposed to glyphosate to determine its possible influence on genetic material.

\section{Acknowledgments}

We are grateful to Dr. Adolfo Maldonado, specialized in tropical medicine, for providing us the blood samples analyzed in this study. He is member of Ecological Action Foundation and part of the group of investigators of the "International Commission of Impact over Ecuadorian territory of Aerial Fumigations in Colombia" FUNDACYTPUCE PIC 015 Project.

\section{References}

Albertini RJ, Nicklas JA and O'Neill JP (1996) Future research directions for evaluating human genetic and cancer risk from environmental exposures. Environ Health Perspect 104:503-510.

Anderson D, Yu TW, Phillips BJ and Schmezer P (1994) The effects of various antioxidants and other modifying agents on oxygen-radical-generated DNA damage in human lymphocytes in the comet assay. Mutat Res 307:261-271.

Arbuckle TE, Lin Z and Mery LS (2001) An exploratory analysis of the effect of pesticide exposure on the risk of spontaneous abortion in an Ontario farm population. Environ Health Perspect 109:851-857.

Batt BD, Black JA and Cowan WF (1980) The effects of glyphosate herbicide on chicken egg hatchability. Can J Zool 58:1940-1942.

Blasiak J, Jaloszynski P, Trzeciak A and Szyfter K (1999) In vitro studies on the genotoxicity of the organophosphorus insecticide malathion and its two analogues. Mutat Res 445:275283.

Bolognesi C (2003) Genotoxicity of pesticides: A review of human biomonitoring studies. Mutat Res 543:251-272.

Carbonell E, Xamena N, Creus A and Marcos R (1993) Cytogenetic biomonitoring in a Spanish group of agricultural workers exposed to pesticides. Mutagenesis 8:511-517.

Carlisle SM and Trevors JT (1988) Glyphosate in the environment. Water Air Soil Pollut 39:409-420.

Evans DD and Batty MJ (1986) Effects of high dietary concentrations of glyphosate on a species of bird, marsupial and rodent indigenous to Australia. Environ Toxicol Chem 5:399-401.

Garaj-Vrhovac V and Zeljezic D (2000) Evaluation of DNA damage in workers occupationally exposed to pesticides using single-cell gel electrophoresis (SCGE) assay. Pesticide genotoxicity revealed by comet assay. Mutat Res 469:279-285.

Goldstein DA, Acquavella JF, Mannion RM and Farmer DR (2002) An analysis of glyphosate data from the California Environmental Protection Agency Pesticide Illness Surveillance Program [Abstract]. J Toxicol Clin Toxicol 40:885892.
Leroy T, van Hummelen P, Anard D, Castelain P, Kirsh-Volders M, Lauwerys R and Lison D (1996) Evaluation of three methods for the detection of DNA single-strand breaks in human lymphocytes: Alkaline elution, nick translation, and single-cell gel electrophoreis. J Toxicol Environ Health 47:409-422.

Lioi MB, Scarfi MR, Santoro A, Barbieri R, Zeni O, Di Berardino D and Ursini MD (1998) Genotoxicity and oxidative stress induced by pesticide exposure in bovine lymphocyte cultures in vitro. Mutat Res 403:13-20.

McKelvey-Martin VJ, Green MHL, Schmezer P, Pool-Zobel B., De Méo MP and Collins A (1993) The single cell gel electrophoresis assay (Comet assay): A European review. Mutat Res 288:47-63.

Monroy CM, Cortes AC, Sicard DM and de Restrepo HG (2006) Cytotoxixity and genotoxicity of human cells exponed in vitro to glyphosate. Biomedica 25:335-45.

Paz-y-Miño C, Bustamante G, Sánchez ME and Leone PE (2002a) Cytogenetic monitoring in a population occupationally exposed to pesticides in Ecuador. Environ Health Perspect 110:1077-1080.

Paz-y-Miño C, Dávalos MV, Sánchez ME, Arévalo M and Leone PE (2002b) Should gaps be included in chromosomal aberration analysis? Evidence based on the comet assay. Mutat Res 516:57-61.

Richard S, Moslemi S, Sipahuta H, Benachour N and Seralini GE (2005) Differential effects of glyphosate and Roundup on human placental cells and aromatase. Environ Health Perspect 113:716-720.

Scarpato R, Migliore L, Angotzi G, Fedi A, Miligi L and Loprieno N (1996) Cytogenetic monitoring of a group of Italian floriculturists: No evidence of DNA damage related to pesticide exposure. Mutat Res 367:73-82.

Slamenová D, Gábelová A, Chalupa I, Szabová E, Mikuláová M, Horváthová E, Ruzekova L, et al. (1999) Cytotoxic and genotoxic effect of inhibitor of vulcanisation $\mathrm{N}$-cyclohexylthiophthalimide in a battery of in vitro assays. Mutat Res 446:35-48.

Singh NP, McCoy MT, Tice RR and Schneider EL (1988) A simple technique for quantitation of low levels of DNA damage in individual cells. Exp Cell Res 175:184-191.

Steenland K, Carrano A, Ratcliffe J, Clapp D, Ashworth L and Meinhardt T (1986) A cytogenetic study of papaya workers exposed to ethylene dibromide. Mutat Res 170:151-160.

Tice RR, Andrews PW and Singh NP (1990) The single cell gel assay: A sensitive technique for evaluating intercellular differences in DNA damage and repair. Basic Life Sci 53:291301.

U.S. Forest Service (1997) Glyphosate: Herbicide Information Profile. Pacific Northwest Region, United Stated Drug Administration (bulletin), Washington, pp 25.

Williams GM, Kroes R and Munro IC (2000) Safety evaluation and risk assessment of the herbicide Roundup and its active ingredient, glyphosate, for humans. Regul Toxicol Pharm 31:117-165.

\section{Internet Resources}

Alaska Community Action on Toxics (ACAT) (1998). Facts About Glyphosate Roundup, Rodeo, Accord, http://www. 
akaction.net/REPORTS/glyphosate fact sheet.pdf (June 13th, 2005).

Acción Ecológica (2003) Impacto de las Fumigaciones del Plan Colombia en la Frontera Ecuatoriana. La guerra oculta contra las comunidades. Acción Ecológica, Quito:85 1-52, http://www.accionecologica.org (June $8^{\text {th }}, 2005$ ).

Acción Ecológica (2004) Frontera: Daños genéticos por las fumigaciones del Plan Colombia. Acción Ecológica, Quito, pp 1-48, http://www.accionecologica.org (June 8th, 2005).

Ministerio de Relaciones Exteriores (2003) Misión de Verificación. Impactos en el Ecuador de las fumigaciones realizadas en el Departamento del Putumayo dentro del Plan Colombia.
Ministerio de Relaciones Exteriores: Ecuador. Informe técnico [in Spanish], http://www.accionecologica.org/webae/ images/docs/fumigaciones/Informe $\% 20$ Fumigaciones $\% 20$ Julio\%202003-espa_ol.pdf (October 26th, 2006).

Nivia E (2001) Aerial spraying of illicit crops is dangerous- some approximations. Paper presented in Spanish to the conference Wars in Colombia: Drugs, Guns and Oil, University of California, Davis, 17-19 May 2001.

http://www.nadir.org/nadir/initiativ/agp/campecuador/spanish/ doc/fumigacion.htm (October 26th, 2006).

Associate Editor: Catarina S. Takahashi 